\title{
IMPACT OF PROCESSING ON SURFACE STRUCTURE OF HUMAN CARDIAC VALVE ALLOGRAFTS
}

\author{
Otakar Krs ${ }^{1}$, Dáša Slízová ${ }^{1}$, Jan Burkert ${ }^{2}$, Jaroslav Špatenka², Petr Hottmar ${ }^{3}$ \\ Charles University in Prague, Faculty of Medicine in Hradec Králové, Czech Republic: Department of Anatomy ${ }^{1}$, \\ Department of Forensic Medicine'; University Hospital Motol, Prague: Transplant Center ${ }^{2}$
}

Summary: Methods of processing and cryopreservation are believed to be the most important factors of long term clinical performance of biological heart valve prostheses. That is why we decided to cooperate in evaluating the impact of current AHV (allograft heartvalve) bank protocol on valve tissue morphology. AHV harvested from „heart-beating“ cadaveric donors, considered as a fresh tissue, were compared with valve samples from non-heart beating donors, samples stored in saline, samples treated with antibiotic solution, and finally with cryopreserved valves, stored in liquid nitrogen for months. All samples were dissected, dried with hexamethyldisilazane (HMDS) method, gold-coated, studied and photographed in scanning electron microscope Tesla BS 301. Different superficial patterns were found on ventricular and vascular surfaces of "fresh" semilunar valves. We were able to detect early changes of endothelium after harvesting, denudation of endothelial covering during preservation with and without freezing. Our alternative method of drying samples by HMDS method proved to be suitable for thin membranes of human semilunar valves. Scanning electron microscopy seems to be helpful for morphological control of processing, cryopreservation and liquid nitrogen storage of AHV. We believe that further confrontation of morphological investigation with other methods helps us to develop more suitable protocol of handling AHV in heart valve banking.

Key words: Cardiac semilunar valves; Allograft; Tissue banking; Preservation; Scanning electron microscopy

\section{Introduction}

One method of treatment of inborn and acquired valve diseases is replacement of damaged valves by auto-, allo-, or xenograft (14). Retrospective and morphological studies get evidence that integrity of endothelial covering together with viability of deeper valve structures are decisive for further fate of the transplanted cardiac valve $(3,4,7,11)$. In spite of its immunogenity, the intact endothelium of allograft heart valve (AHV) is able to slow degeneration of implanted graft and its calcification (6). Morphological and functional qualities of cardiac valves are studied by a series of various methods. Human cardiac valves were studied in scanning electron microscope (SEM) early after appropriate devices became available (1). Nevertheless, the unique opportunity to reveal large surface extent of cardiac valves (square centimeters) remains still attractive. That is why we have used a SEM for studying superficial features of valves of various origin stored at different conditions.

\section{Material and Methods}

Control group of aortic and pulmonary valves came from heart-beating donors. Surface morphology of these AHVs was compared with (1) tissue from semilunar valves obtained from non heart-beating donors, (2) valve samples stored in $+4{ }^{\circ} \mathrm{C}$ saline for 24 hours, (3) antibiotic-treated tissue (cefuroxime $0.2 \mathrm{mg} / \mathrm{ml}+$ piperacilline $0.2 \mathrm{mg} / \mathrm{ml}+$ netilmicine $0.1 \mathrm{mg} / \mathrm{ml}+$ fluconazole $0.1 \mathrm{mg} / \mathrm{ml}$ ) at $37^{\circ} \mathrm{C}$, and finally (4) cryopreserved valves, stored in liquid nitrogen $\left(-196{ }^{\circ} \mathrm{C}\right)$ for months. Valves were initially fixed in Baker's fluid, selected parts (about $5 \times 5 \mathrm{~mm}$ ) were mounted on convex polystyrene casts with help of hedgehog spines. Valve specimens are fixed in $4 \%$ formaldehyde overnight, then washed in distilled water for 5 minutes, and dehydrated in a graded ethanol series $(70 \%, 85 \%, 95 \%$, and $100 \%$ ) for 5 minutes at each level. The tissue samples are then immersed in 100\% hexamethyldisilazane (CAS No. 999-97-3; Fluka Chemie AG, Buchs, Switzerland) for 10 minutes and air dried in an exhaust hood at room tempera- 


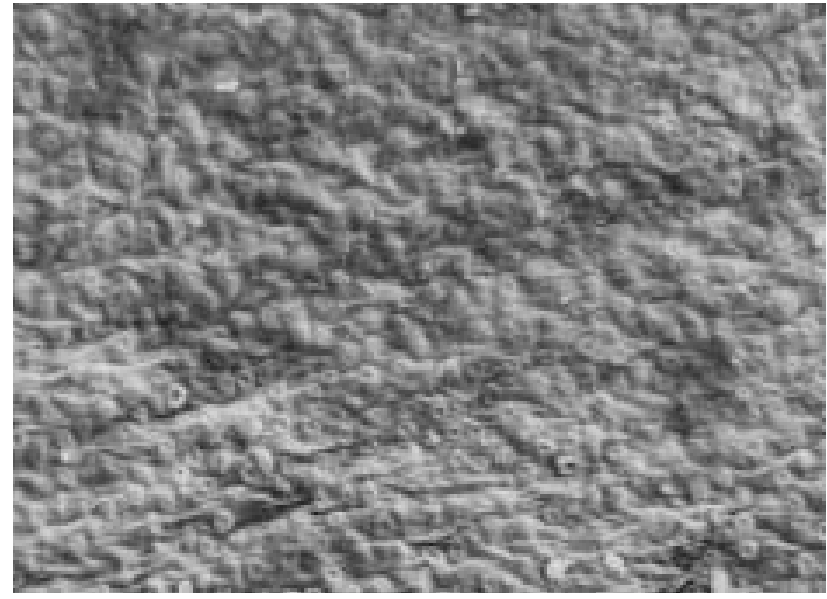

Fig. 1: Control sample of aortic valve, ventricular surface. „Fresh“ tissue from heart-beating donor, initial storage in saline at ambient temperature for 20 minutes. Confluent irregular endothelial pattern with central excavation on endotheliocytes 470x.
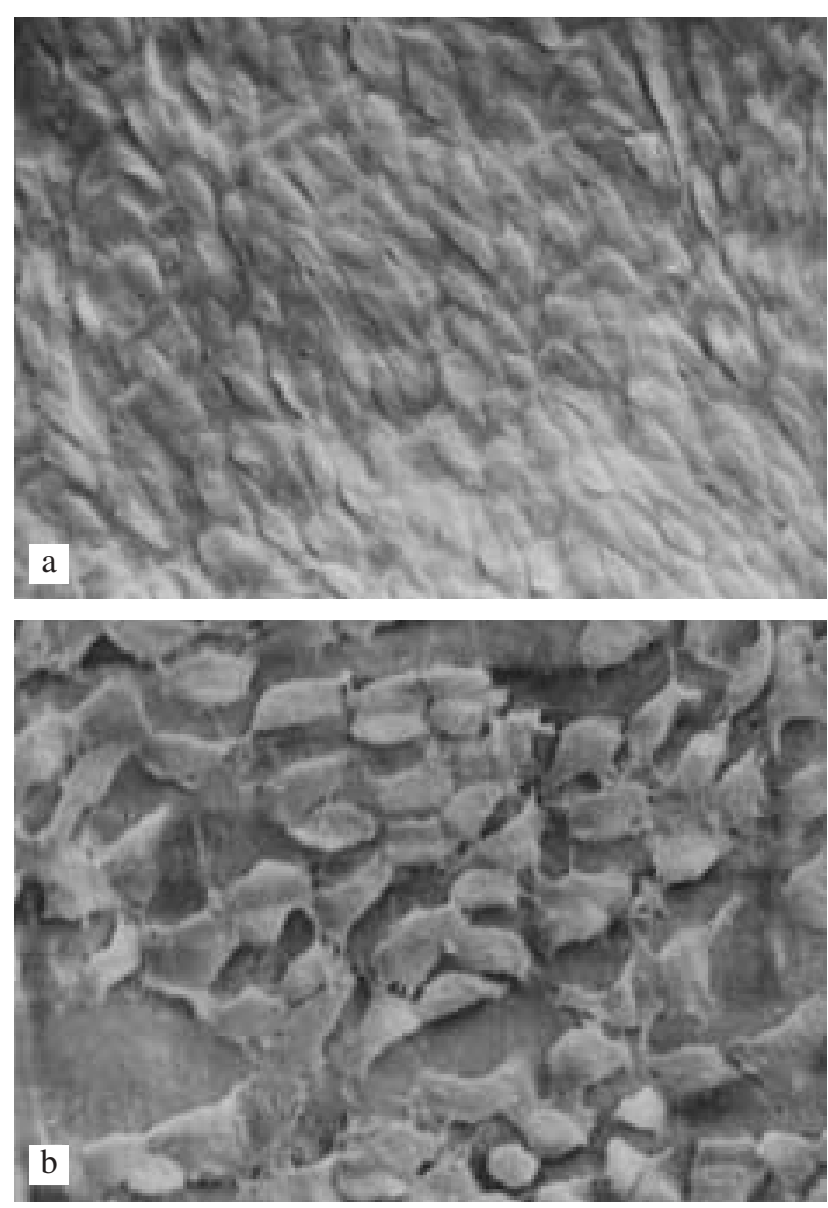

Fig. 2: Aortic valve, ventricular surface, after „warm“ ischemia (sampled 12 hours after death). A: Initial separation of ECs from basal membrane 1000x. B: Advanced separation with dissociated intercellular contacts $2200 \mathrm{x}$. ture (12). Large specimens underwent at least one bath in a graded ethanol-HMDS solution before immersion in a pure HMDS bath. Processed specimens were mounted on stainless steel stubs, coated with gold, and stored in a desiccator until studied and photographed in a BS 301 scanning electron microscope (Tesla Brno, Czech Republic).

\section{Results}

Superficial relief of aortic and pulmonary valves studied revealed these typical features:

Control sample of aortic valve (fresh tissue - operation sample, initially stored in saline at ambient temperature for 20 minutes ) - ventricular surface of aortic valve is covered by confluent endothelial layer. However, the endothelial pattern is rather irregular, with frequent central excavations on cell membranes of endotheliocytes (Fig. 1).

(1) Aortic valve from non heart-beating donor (autopsy, 12 hours after death) - commencing separation of endothelial cells (ECs) from basal membrane (BM), some ECs face lumen by their elevated longitudinal edges (Fig. 2A). On other site of the same surface, it is possible to observe shrinking and separation of ECs with partly dissociated intercellular contacts (Fig. 2B).

(2) Pulmonary valve stored in saline for 24 hours at $4{ }^{\circ} \mathrm{C}$ - ventricular surface is completely stripped of ECs, lamina ventricularis is exposed, with only scarce remnants of BM (Fig. 3).

(3) Pulmonary valve treated by antibiotics at $37{ }^{\circ} \mathrm{C}-$ there are only a few ECs on ventricular surface, lamina ventricularis is exposed. There are only solitary ECs on the vascular surface of the valve, superficial ridging is caused by deeper lamina fibrosa (Fig. 4).

(4) Valves thawed after some months of storage in liquid nitrogen $\left(-196^{\circ} \mathrm{C}\right)$. Both ventricular and vascular sur-

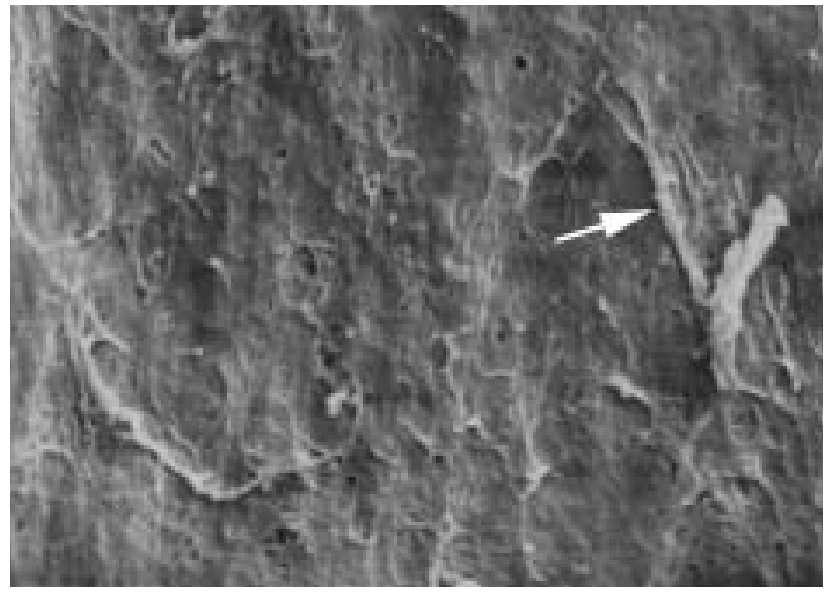

Fig. 3: Pulmonary valve, ventricular surface, „cold“ ischemia in saline for 24 hours at $+4{ }^{\circ} \mathrm{C}$. Missing endothelial covering with exposed lamina ventricularis, remnants of basal membrane (arrow) 3000x. 


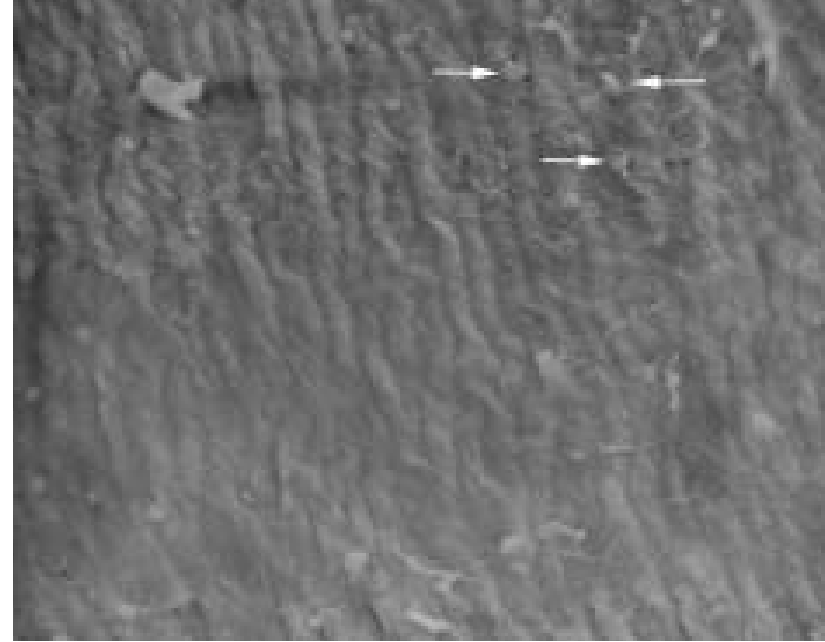

Fig. 4: Pulmonary valve, vascular surface, after „cold“ ischemia in preservation medium E199 with antibiotics for 7 days. Only a few ECs are present (arrows) 710x.

faces of aortic valve are completely denuded of ECs and BM. Lamina ventricularis and lamina fibrosa are exposed. Similar changes are visible on both surfaces of pulmonary valve (Fig. 5).

\section{Discussion and Conclusions}

Our results support an opinion that any „non-physiological" manipulation with valve tissue results in remarkable changes of surface features. Besides expected negative impacts of freezing and thawing of allografts we observed negative effect of saline, that was remarkable in case of preserved venous grafts, too (10). That is why we recommend to avoid even short-time effect of saline and to prefer the immediate use of preservation fluids used currently for transplantation of other organs (13). From comparison of our results with pictorial documentation of other authors $(5,8)$ we can conclude that our method developed for desiccation of vascular samples proved to be suitable for preparation of fine and thin sheets of semilunar valves. Scanning electron microscopy of superficial features of AHV is advantageous for its ability to cover relatively large area of a sample. It is especially valuable for detection of change gradients along the endothelial surface resulting from rheological circumstances (9). This method is also usable for analysis of explanted grafts (2) and bioptic specimens of degenerated valves. Scanning electron microscopy may be helpful for morphological evaluation of processing, cryopreservation, and long term cryogenic storage of AHV. We suppose that further confrontation and complementing of SEM with other methods (mainly with tissue viability testing) helps us to work out more suitable protocol of handling AHV in heart valve banking.

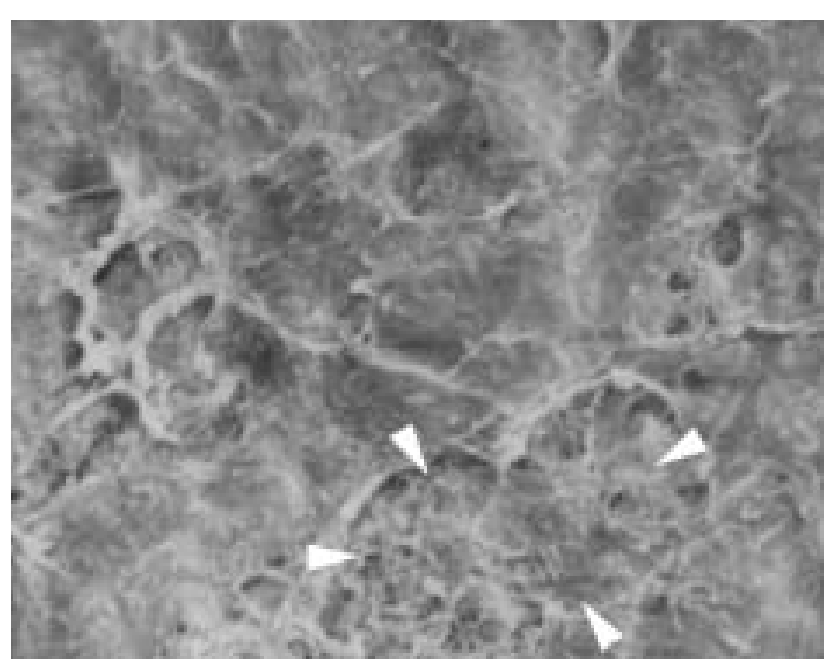

Fig. 5: Pulmonary valve, ventricular surface, after cryogenic storage lasting 12 months and thawing. Damaged BM with partly exposed lamina ventricularis (arrowheads) 2700x.

\section{References}

1. Hammon JW, O'Sullivan MJ, Oury J, Fosburg RG. Allograft cardiac valves. A view through the scanning electron microscope. J Thorac Cardiovasc Surg 1974;68:352-60.

2. Koolbergen DR, Hazekamp MG, de Heer E et al. The pathology of fresh and cryopreserved homograft heart valves: An analysis of forty explanted homograft valves. J Thorac Cardiovasc Surg 2002;124:689-97.

3. Lis GJ, Rokita E, Podolec P, Pfitzner R, Dziatkowiak A, Cichocki T. Mineralization and organic phase modifications as contributory factors of accelerated degeneration in homograft aortic valves. J Heart Valve Dis 2003;12:741-51.

4. Lund $\mathrm{O}$, Chandrasekharan V, Grocott-Mason R et al. Primary aortic valve replacement with allografts over twenty-five years: Valve-related and procedure-related determinants of outcome. J Thorac Cardiovasc Surg 1999;117:77-91.

5. Lupinetti FM, Tsai TT, Kneebone JM, Bove EL. The effect of cryopreservation on the presence of endothelial cells of human valve allografts. J Thorac Cardiovasc Surg 1993;106:912-7.

6. Mirzaie M, Meyer T, Schwartz P, Dalichau H. Preimplant ultrastructure and calcification tendency of various biological aortic valves. J Heart Valve Dis 2000; 9:576-82.

7. Mitchell RN, Jonas RA, Schoen FJ. Structure-function correlations in cryopreserved allograft cardiac valves. Ann Thorac Surg 1995;60:S108-13.

8. Mohan R, Feng XJ, Walter P, Herman A. Cryopreserved heart valve allografts can have a normal endothelium. J Thorac Cardiovasc Surg 1994;108:985-7.

9. Nicosia MA, Cochran RP, Einstein DR, Ruthland CJ, Kunzelman KS. A coupled fluid-structure finite element model of the aortic valve and root. J Heart Valve Dis 2003; 12:781-9.

10. Páral J, Ferko A, Měřička $P$ et al. Př́spěvek ke konzervaci žilních štěpů. Rozhl Chir 2000;79:244-9.

11. Simionescu DT, Lovekamp JJ, Vyavahare NR. Degeneration of bioprosthetic heart valve cusp and wall tissues is initiated during tissue preparation: An ultrastructural study. J Heart Valve Dis 2003;12:226-34

12. Sližová D, Krs O, Pospíšilová B. Alternative method of rapid drying vascular specimens for scanning electron microscopy. J Endovasc Ther 2003;10:285-7.

13. Špatenka J, Kostelka M, Kobylka P et al. Příprava, skladování, transport a použit allotransplantátů srdečních chlopní. Rozhl Chir 1997;76:118-25.

14. Yankah AC. Forty years of homograft surgery. Asian Cardiovasc Thorac Ann 2002;10:97-100.

Submitted March 2004.

Accepted May 2004.

MUDr. Otakar Krs, CSc., Charles University in Prague, Faculty of Medicine in Hradec Králové, Department of Anatomy, Šimkova 870, 50038 Hradec Králové, Czech Republic. e-mail: krs@lfhk.cuni.cz 